J. Perinat. Med. 15 (1987) 83

\title{
Maternal residual beta-cell function and the outcome of diabetic pregnancy
}

\author{
Heikki I. Pirttiaho, Anna-Liisa Hartikainen-Sorri, Pekka Kääpä, Jorma M. \\ Kaila, and Raija Puukka
}

Departments of Internal Medicine, Obstetrics and Gynaecology, Pediatrics, and Clinical Chemistry, University of Oulu, Finland

\section{Introduction}

The importance of strict glucose control to the outcome of diabetic pregnancy has been demonstrated in several recent studies $[1,2,4,5$, $6,10]$. The main facilities for good control are provised by multiple-dose insulin administration, appropriate dietary management, continuous patient education and home blood glucose monitoring together with sequential estimations of blood glycosylated hemoglobin [6]. In addition to this "exogenous" management of the pregnant diabetic, her endogenous insulin production also may be involved in the achievement of strict glucose control. The importance of residual beta-cell function during gestation has been minimally investigated although there are numerous studies on its prevalence and clinical significance in non-pregnant subjects [7]. Recently we demonstrated improvement in residual beta-cell activity during gestation [8] which led our attention to its influence on the outcome of pregnancy.

\section{Methods}

Twenty-nine pregnant diabetic women were studied. Twenty-four of them were juvenile-onset ketosis-prone insulin-dependent subjects. The remaining five subjects had insulin treatment during gestation only, although all had abnormal glucose tolerance both antedating

\section{Curriculum vitae}

HeIKKI I. PIRTTIAHo, M.D., was born in 1945 in Northern-Finland. He studied medicine from 1964 to 1971, when he qualified as a general physician. He specialized in internal medicine at the University of Oulu 1973-1976. In 1978 he defended his doctoral thesis. Since 1978 he has been a lecturer in the Department of Medicine of the University of Oulu. His main fields of interest include clinical pharmacology and diabetology.

pregnancy and after delivery. The subjects were divided into the groups of moderate (CPR > $1.0 \mu \mathrm{g} / 1$, group I) and minimal (CPR $<1.0 \mu \mathrm{g} /$ 1, group II) residual beta-cell activity on the basis of their mean stimulated plasma C-peptide (CPR) values during gestation. They were also classified according to WHITE [14]. The clinical data of the two diabetic groups are shown in table I.

Values of plasma CPR and blood $\mathrm{Hb} \mathrm{A}_{1 \mathrm{c}}$ were measured in an obstetrical ward during $11-12$, $23-24,32-33$ and $37-38$ gestational weeks. CPR measurement was done after a standardized breakfast (400 kcal; $35 \mathrm{~g}$ carbohydrate, $30 \mathrm{~g}$ protein, $15 \mathrm{~g}$ fat). A twenty-four hour glucose curve with four hour intervals was measured at each control admission. 
Plasma C-peptide immunoreactivity was measured with a commercial kit (RIA-mat C-peptide, Byk-Mallincrodt RadiopharmazeutikaDiagnostica, GFR) and $\mathrm{Hb} \mathrm{A}_{1 \mathrm{c}}$ levels by the ion-exchange chromatographic method of TRIVELLI et al. [13]. The sensitivity of CPR assays was $0.1 \mathrm{ug} / 1$ and the interassay coefficient of variation 7 per cent. The normal range of $\mathrm{Hb}$ $\mathrm{A}_{1 \mathrm{c}}$ in healthy non-pregnant subjects was 4.1-6.1 per cent. The measurements of blood glucose concentrations were performed by the hexokinase method. The daily fluctuation of blood glucose was studied by counting the mean amplitude of glucose excursions [9].

The treatment of diabetes during gestation was conventional with highly-purified insulins (Novo-Industri A/S, Denmark, and Nordisk Insulinlaboratorium, Denmark), and appropriate diet.

Regular obstetrical follow-up began at the first hospital visit, and the patients were admitted to the obstetrical ward from the 32nd gestational week onwards until delivery. Cardiotocography, ultrasound and biochemical monitoring of the fetal well-being were included in the obstetrical care. The time and mode of the delivery were planned individually. The maturity of the fetal lungs was assessed by means of the lecithine/sphingomyelin ration of the amniotic fluid before delivery.

The newborns were monitored in the intensive care unit immediately after birth. The first blood glucose measurements were done $0.5-2 \mathrm{~h}$ after birth and followed three times daily for two consecutive days. Blood glucose values below $1.7 \mathrm{mmol} / 1$ were considered to be hypoglycemic. The newborns' cardiorespiratory state, acid-base balance, serum calcium and bilirubin levels were observed regularly. Serum calcium level below $1.8 \mathrm{mmol} / 1$ was considered hypocalcemic. The need for treatment of hyperbilirubinemia was assessed on the basis of a modified SWYER's curve [12].

The statistical analysis of the data was performed by Student's t-test, one-way analysis of variance, regression analysis, chi-square test and Mann-Whitney test.

\section{Results}

The mean postprandial CPR-values of the two groups are shown in figure 1 and the parameters of glucose control are summarized in table I. Moderate residual beta-cell activity (group I) was associated with significantly better glucose control. Also the mean amplitude of glucose excursions in this group was significantly smaller than in subjects with minimal or lacking beta-cell function ( 2.6 vs. $4.8 \mathrm{mmol} / \mathrm{l}, \mathrm{p}$ $<0.01$ (Mann-Whitney test)). There was a significant correlation between insulin doses and CPR values in group I $(\mathrm{r}=-0.90, \mathrm{p}<$ $0.001)$ but not in group II $(\mathrm{r}=-0.18, \mathrm{P}=$ nonsignificant).

All White B subjects were included in group I and all D and NF subjects in group II. Subjects in class $B$ had significantly higher CPR values than those in the other classes (figure 1).
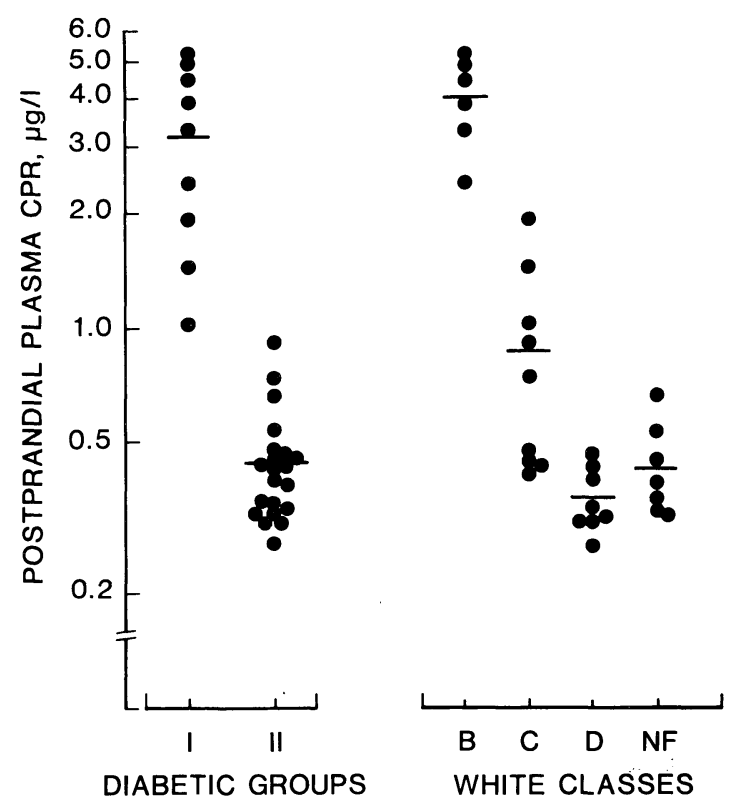

Figure 1. Mean postprandial CPR values in the two diabetic groups and in the various White classes. The values in group I were significantly higher than in group II ( $p<0.001$, Student's $t$-test), and the values in White class $B$ were significantly higher than in the other classes ( $p<0.01$, one-way analysis of variance). 


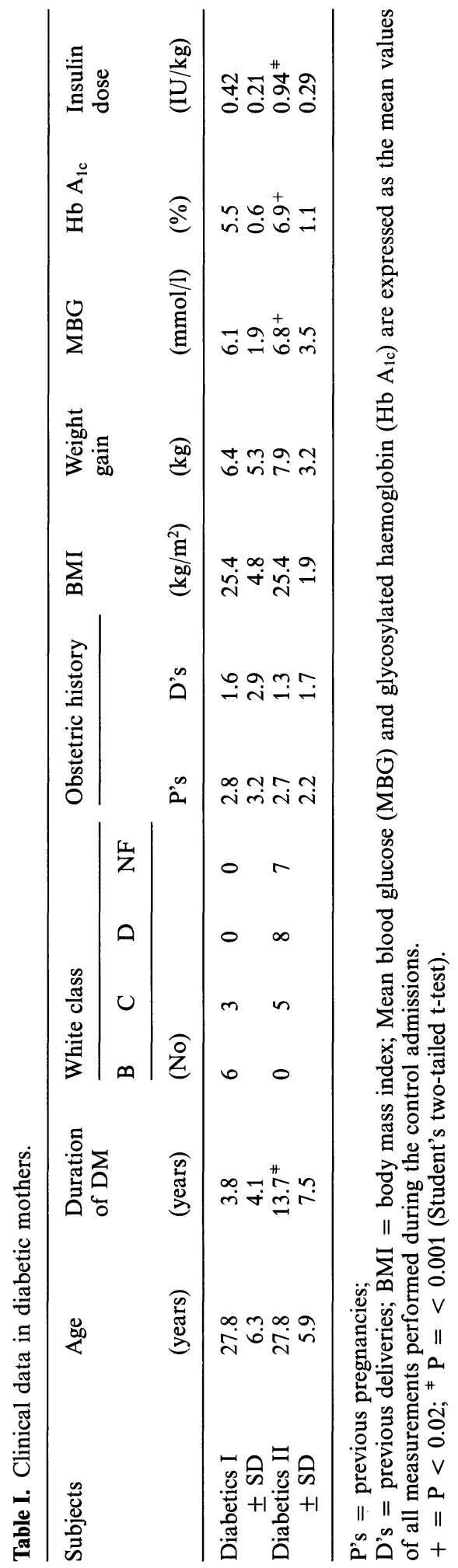

The outcome of pregnancy in the two groups is shown in table II and in the various White classes in table III. Fetal wastage was seen only in group II, in which there were two intrauterine deaths (White classes $\mathrm{C}$ and D). One took place in the 28th gestational week because of multiple congenital contracture syndrome, a lethal and autosomally recessive disorder. The other was in the 33rd gestational week of a twin pregnancy, where the first twin died because of severe intrauterine growth retardation without any evident cause, the second twin growing normally. There was no postnatal mortality. The only congenital malformation in a living newborn was seen in group I (White class B). The mother was 40 years old and had a twin pregnancy, the first twin was a trisomy 21 infant with congenital heart defect and an annular pancreas.

All infants suffering from RDS were in group II. In two cases delivery occured spontaneously in the 34-35 gestational weeks and in two cases cesarean section was done because of intrauterine asphyxia in the 32nd and 35th gestational week.

There was no difference in the frequency of hyperbilirubinemia in the two groups. Only in two cases was hyperbilirubinemia treated with blood exchange therapy, one in both groups.

There was no statistical difference in the occurence of hypoglycemia between the groups. Of six cases needing intravenous glucose infusion, five belonged to group II. The birthweight of infants was lower in group II but the difference was not significant. The birthweight of infants in White classes B and C was significantly higher than in class NF which also included all the cases with RDS. There was no other difference in neonatal morbidity between the classes.

\section{Discussion}

The results of the present study suggest that moderate residual beta-cell activity had beneficial effects on glycemic control during diabetic pregnancy. Its influence on the outcome of pregnancy was less clear. However, the subjects 


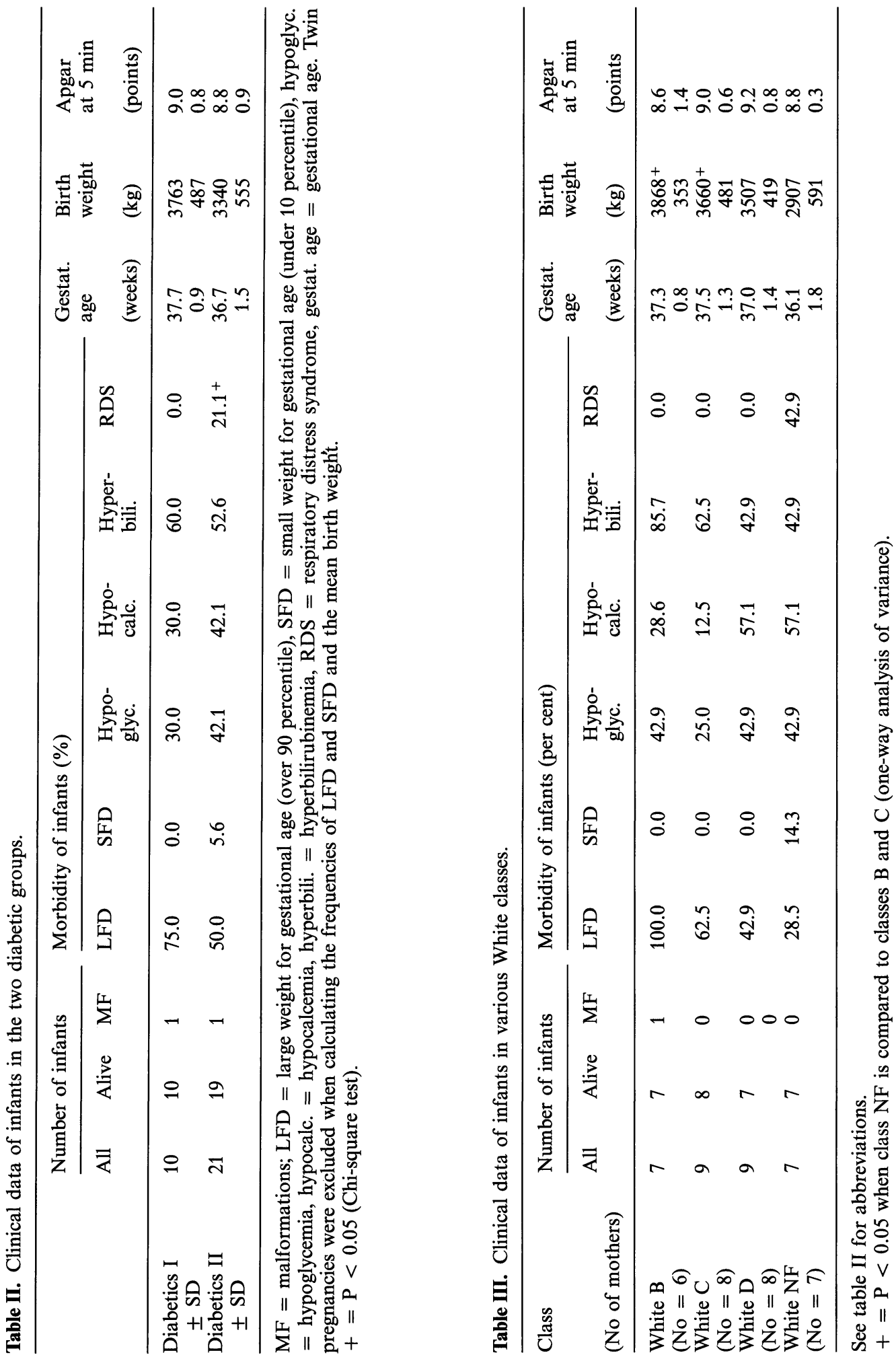


with higher CPR values (group I) showed no fetal wastage and less serious neonatal morbidity. Although the two perinatal deaths in group II cannot be directly connected to diabetes mellitus in the mother, the infants in this group showed significantly greater incidence of RDS and a trend to smaller birth weight. The association of preserved beta-cell function with the better outcome of pregnancy agrees well with the previous results of STANGENBERG et al. [11].

The strict criteria of neonatal complications in the present study made the apparent incidence of hypoglycemia and hyperbilirubinemia quite high. However, only a minority of infants needed specific treatment such as intravenous glucose infusion or blood exchange. Also the high incidence of large for date infants in White class B mothers needs special attention. This finding could not be due to poor glucose control in the late pregnancy since both the values of $\mathrm{Hb} \mathrm{A}_{1 \mathrm{c}}$ and mean blood glucose were even better than in the other White classes. However, prolonged fetal- exposition to maternal hyperglycemia with its consequences could have been possible in the early pregnancy since these subjects generally were admitted to the hospital later than the others, the insulin treatment in some cases beginning not until 29-30 weeks of gestation.

\section{Summary}

Preservation of own insulin production (residual pancreatic beta-cell function) has been shown to have a beneficial effect on glycemic control in insulin-dependent diabetic subjects, and its total lack has been suggested to be an independent risk factor during diabetic pregnancy. We studied the influence of residual beta-cell activity on the glucose control and the outcome of pregnancy in 29 diabetic women by sequentially measuring gestational postprandial plasma C-peptide (CPR) levels, diurnal blood glucose curves and blood glycosylated hemoglobin $\left(\mathrm{Hb} \mathrm{A}_{1 \mathrm{c}}\right)$ and by analyzing the morbidity and mortality of the offsprings.

The 9 diabetics with moderate own insulin secretion (CPR levels over $1.0 \mathrm{ug} / \mathrm{l}$, White classes B and C, later referred to as group I) had significantly better glucose control than the remaining 20 subjects with lower CPR values (White classes C, D and NF, later referred to as group II) (figure 1, table I). There were two intrauterine deaths, both in group II. These deaths (one caused by
White classification is the cornerstone in predicting the outcome of diabetic pregnancy. However, it takes into account the age at the onset and the duration of diabetes and its vascular complications, but not the glucose control or factors influencing it. Hence, lack of residual beta-cell function has been suggested to be an independent risk factor, giving prognostic information not obtained by White classification [11]. In the present study, the evaluation of the independent predictive value of residual beta-cell function is difficult, although the two groups were well comparable in most respects. The distribution of White classes was uneven, however; class B was over-represented in group I which also included no subjects from classes D and NF. The finding was expectable since residual beta-cell function decreases with the duration of diabetes [7] which is also one of the main factors in White classification. In the previous study of STANGENBERG et al. [11] class B was also over-represented in the group with residual beta-cell function (three out of five subjects) as compared to those without measurable CPR values (one out of five subjects). Studies with larger groups matched for White classes are needed to eliminate the possible bias and to verify the independent value of CPR measurements in predicting the outcome of diabetic pregnancy.

multiple congenital contracture syndrome and the other by severe intrauterine growth retardation without any evident cause) could not be straightly connected with diabetes. Respiratory distress syndrome was seen in group II only. There was no other significant difference in the neonatal morbidity between the two groups (table II). All mothers of RDS infants were in White class NF where the birthweight was also smaller than in classes $B$ and $C$. These were the only differences in neonatal morbidity between the White classes (table III).

In conclusion, moderate residual beta-cell function seemed to be clinically important in maintaining strict glucose control during gestation. Its value as an independent risk factor was less clear because of the uneven distribution of White classes in the two diabetic groups (all White B subjects in group I and all D and NF subjects in group II). Further studies are needed to ascertain whether the measurements of CPR can be employed to complete White classification and to help in assessing the prognosis of pregnancy more accurately.

Keywords: C-peptide, insulin-dependent diabetes mellitus, pregnancy in diabetes, residual beta-cell function. 


\section{Zusammenfassung}

\section{Maternale residuale $\beta$-Zellfunktion und Verlauf und Aus- gang diabetischer Schwangerschaften}

Die Erhaltung der eigenen Insulinproduktion bei noch vorhandenen $\beta$-Zellen im Pankreas hat einen günstigen Einfluß auf den Blutglukosespiegel bei insulinabhängigen Diabetikern. Der totale Ausfall muß als eigenständiger Risikofaktor bei diabetischen Schwangerschaften angesehen werden. Wir untersuchten die Auswirkungen noch vorhandener $\beta$-Zellenaktivität auf die Regulation des Glutglukosespiegels bei 29 schwangeren Diabetikerinnen. Dazu wurden in bestimmten Abständen die postprandialen C-Peptidspiegel im Plasma (CPR), die Blutzuckertagesprofile sowie das glykolysierte Hämoglobin $\left(\mathrm{Hb}_{1 \mathrm{c}}\right)$ gemessen und post partum Morbidität und Mortalität der Neugeborenen erfaßt.

Die 9 Diabetikerinnen mit mäßiger eigener Insulinproduktion (CPR-Spiegel $>1.0 \mu \mathrm{g} / 1$, B und $\mathrm{C}$ nach der White-Klassifikation, in unserer Studie Gruppe I) waren deutlich besser eingestellt als die übrigen 20 Frauen mit niedrigeren CPR-Werten (C, D und NF nach der WhiteKlassifikation, in unserer Studie Gruppe II, Abb. 1, Tabelle I). Die beiden intrauterinen Fruchttode entfielen auf die Gruppe II. In einem Fall lagen multiple kongeni- tale Kontrakturen vor, im anderen Fall eine schwere intrauterine Wachstumsretardierung. Ein direkter $\mathrm{Zu}-$ sammenhang mit dem Diabetes bestand nicht. Atemnotsyndrome wurden nur in der Gruppe II beobachtet. Andere signifikante Unterschiede hinsichtlich der neonatalen Morbidität gab es zwischen den beiden Gruppen nicht (Tabelle II). Alle Mütter von Kindern mit RDS waren in der Gruppe NF nach der White-Klassifikation. Hier lagen die Geburtsgewichte auch niedriger als in den Gruppen B und C. Darüber hinaus gab es keine weiteren Unterschiede hinsichtlich der neonatalen Morbidität zwischen den White-Gruppen (Tabelle III).

Zusammenfassend scheint eine mäßige residuale $\beta$-Zellen Funktion für die Einstellung des Blutglukosespiegels während der Schwangerschaft von großer klinischer Bedeutung $\mathrm{zu}$ sein. Diese Bedeutung als eigenständiger Risikofaktor war wegen der ungleichen Verteilung der White-Gruppen auf die Gruppeneinteilung unserer Studie weniger klar. Weitere Untersuchungen sind notwendig, um zu sichern, ob Messungen des CPR als Ergänzung zur White-Klassifikation sinnvoll sind und so die Schwangerschaftsprognose genauer erfaßt werden kann.

Schlüsselwörter: C-Peptid, insulinabhängiger Diabetes mellitus, residuale $\beta$-Zellenfunktion, Schwangerschaft und Diabetes.

\section{Résumé}

Fonction cellulaire $\beta$-résiduelle maternelle et devenir des grossesses des diabétiques

Il a été montré que la conservation de la production d'insulin personnelle (fonction $\beta$ cellulaire panréatique résiduelle) exerce un effet bénéfique sur le contrôle glycémique chez les sujets diabétiques insulino-dépendants et il a été suggéré que l'absence complète d'insuline est un facteur de risque indépendant au cours de la grossesse chez la diabétique. Nous avons étudié l'influence de l'activité $\beta$ cellulaire résiduelle sur le contrôle glycémique et sur le devenir de la grossesse chez 29 femmes diabétiques en mesurant de façon séquentielle les taux plasmatiques de-C peptide (CPR) post-prandial pendant la grossesse, les courbes de glycémie diurne et l'hémoglobine glycosylée sanguine $\left(\mathrm{Hb} \mathrm{A}_{1 \mathrm{c}}\right)$ et en analysant la morbidité et la mortalité des nouveaux-nés.

Les 9 femmes diabétiques ayjant une sécrétion modérée d'insuline persistance (CPR $>1,0 \mu \mathrm{g} / \mathrm{l}$, de classe B et $\mathrm{C}$ de White, ultérieurement placées en groupe I) ont de façon significative un meilleur contrôle glycémique que les 20 autres patientes ayant des valeurs inférieures de CPR (classes C, D et NF de White, ultérieurement classées en groupe II) (figure 1, tableau I). Il y a eu deux morts fotales in utero, toutes les deux dans le groupe II. Ces morts fotales (l'une provoquée par un syndrome de contractures congénitales multiples, l'autre par un retard de croissance intra-utérin majeur sans cause évidente) ne peuvent être mises étroitement en relation avec le diabète. On n'a observé de syndrome de détresse respiratoire que dans le groupe II. Il n'y a pas eu d'autre différence significative entre les deux groupes (tableau II). Toutes les mères d'entants avec SDR étaient dans la classe NF de White, classe pour laquelle les poids de naissance sont inférieurs à ceux des classes $\mathrm{B}$ et $\mathrm{C}$. Il s'agit là des seules différences entre les classes de White pour la morbidité néonatale (tableau III).

En conclusion, une fonction beta-cellulaire résiduelle modérée semble être cliniquement importante pour maintenir un contrôle glycémique strict au cours de la grossesse. Sa valeur comme facteur de risque indépendant est moins clair dans la mesure où la distribution était inégale pour les classes de White dans les deux groupes de diabétiques (tous les sujets classe B de White dans le groupe I, et tous les sujets classe D et NF dans le groupe II). Des études ultérieures sont nécessaires pour confirmer que les mesures de CPR peuvent être utilisées pour compléter la classification de White et pour aider à la détermination du pronostic de la grossesise avec une plus grande certitude.

Mots-clés: Diabète sucré insulino-dépendant, fonction cellulaire $\beta$ résiduelle, grossesse chez les diabétiques, peptide C.

Acknowledgements: This study was supported by a grant from the E. Aaltonen's Foundation. 


\section{References}

[1] Adashi EY, H Pinto, JE Tyson: Impact of maternal euglycemia on fetal outcome in diabetic pregnancy. Am J Obstet Gynecol 133 (1979) 268

[2] FuHrmanN K, H Reiher, K Semmler, F Fischer, M FISCHER, E GLÖCKNER: Prevention of congenital malformations in infants of insulin-dependent diabetic mother. Diabetices Care 6 (1983) 219

[3] HARE JW, P WhITE: Gestational diabetes and White classifiation. Diabetes Care 3 (1980) 394

[4] Jovanovic L, M Druzin, CM PETERson: Effect of euglycemia on the outcome of pregnancy in insulindependent diabetic women as compared with normal control subjects. Am J Med 71 (1981) 921

[5] Jovanovic L, CM Peterson: Management of the pregnant, insulin-dependent diabetic women. Diabetes Care 3 (1980) 63

[6] Jovanovic L, CM Peterson, BB Saxena, MY DAWOOD, CD SAUDEK: Feasibility of maintaining normal glucose profiles in insulin-dependent pregnant diabetic women. Am J Med 68 (1980) 105

[7] MadSBAD S: Prevalence of residual B cell function and its metabolic consequences in type 1 (insulindependent) diabetes. Diabetologia 24 (1983) 141

[8] Pirttiaho Hi, AL Hartikainen-Sorri, JM Kaila, R PUUKKA: Residual B-cell function and glycaemic control in diabetic pregnancy. Horm Metab Res (in press)
[9] Service FJ, GD Mulnar, JW Rosewear, E AcKERMAN, LC GATEWOOD, WF TAYLOR: Mean amplitude of glycaemic excursions, a measure of diabetic instability. Diabetes 19 (1970) 644

[10] Skyler JS, MJ O'Sullivan, EG Robertson, DL SKYLER, KK HOLSINGER, IA LASKY, AGW MCLEOD, G BURKETT, DH MinTz: Blood glucose control during pregnancy. Diabetes Care 3 (1980) 69

[11] Stangenberg M, B Persson, BB Redholm, NO LUNELL: Profiles of intermediary metabolites in insulin-dependent pregnant diabetic women with or without endogenous insulin production. Diabetes Care 5 (1982) 409

[12] SWYER PR: The intensive care of the newly born: physiological principles and practice. Karger, Basel 1975

[13] Trivelli LA, HM RanNey, HT LAI: Haemoglobin components in patient with diabetes mellitus. $\mathrm{N}$ Engl J Med 284 (1971) 353

[14] White P: Pregnancy and diabetes. In: Marble A, P White, RF BraDley, LP Krall (eds): Joslin's diabetes mellitus. Lea \& Febiger, Philadelphia 1971

Received July 5, 1985. Revised May 26, 1986. Accepted June 5, 1986.

Heikki I. Pirttiaho, M. D.

Department of Internal Medicine University of Oulu

SF-90220 Oulu 22

Finland 